SOLIAR IHOR,

Ivan Krypiakevych Institute of Ukrainian Studies of the National Academy of Sciences of Ukraine; Hetman Petro Sahaidachnyi National Army Academy (Lviv, Ukraine)

e-mail: isoliar@ukr.net,.ORCID0000-0003-0439-6957

FINOGENOV OLEH,

Ivan Krypiakevych Institute of Ukrainian Studies

of the National Academy of Sciences of Ukraine (Lviv, Ukraine)

e-mail:fom_178@ukr.net, ORCID0000-0002-6666-1624

SKORYCH LILIJA,

Hetman Petro Sahaidachnyi National Army Academy (Lviv, Ukraine)

e-mail: skorychl@ukr.net, ORCID0000-0003-3162-517X

\title{
THE WESTERN UKRAINIAN ASSOCIATION \\ OF THE LEAGUE OF NATIONS: THE IDEOLOGICAL PLATFORM, ACTIVITY AT THE CONGRESSES OF THE LEAGUE OF NATIONS UNION OF ASSOCIATIONS (1922 - 1924)
}

The geopolitical changes in the international relations after the First World War, the new trends in European foreign policy, the increasing interest to the Ukrainian issue were the main reasons which intensified an interest of Ukrainian community to the issues of international policy. Founded in 1922 the Western Ukrainian Association of the League of Nations (WUALN) endeavored to facilitate the solution of the Ukrainian issue in the format of the LNUA, manifesting the idea of Ukrainian statehood renewal. Three periods can be defined in the association's activity: the first includes the period from January-June 1922; it is the time of organization's foundation and its entrance to the League of Nations Union of Associations (LNUA); the second (the main) period from the $8^{\text {th }}$ of June 1922 to the $23^{\text {rd }}$ of June 1923; it is the time of a full membership the WUALN in the Union; the third period from the $23^{\text {rd }}$ of June to the $1^{\text {st }}$ of July 1924 connected with the suspension of the WUALN's membership in the LNUA and the association's struggle for the rights' renewal in the organization. The WUALN did not recognized the Treaty of Versailles about the division of the Ukrainian lands between the Soviet Union, Poland, Romania, Czechoslovakia; the Riga Peace Treaty's ratifications of 1921 between Poland, the Soviet Union and the Ukrainian Republic included to the Soviet Union. The Association had the close contacts and cooperated with the WUNR's government in exile, political parties from the Western Ukraine: Ukrainian National Labor Party (UNLP), Ukrainian Radical Party (URP), Christian Social Party (CSP), Ukrainian Parliament Representation (UPR) and other organizations. The association coordinated actions on the international scene and its tactics with the WUNR's government in exile and E. Petruschevich personally; still the information about the misuses of the Polish government, the facts of violations from the Polish regime of the national minorities' rights, non-performance of the international obligations of the Polish state was obtained from the other civil and political organizations of the WUALN. The contradictions between UNR and WUNR governments influenced on the relations with the Ukrainian Association of the League of Nations (UALN) from Naddniprianschyna in 1919-1920-s; notwithstanding in the strategical lines of the "Ukrainian issue's" solution the both associations demonstrated solidarity and co-coordination that the congress of the LNUA demonstrated vividly in The Hague. However, the contacts with the members of Naddniprianschyna gradually activated after the temporary suspension of WUALN's activity in the LNUA in 1923. At that period the UALN often defended the WUALN's interests in the governing bodies of the LNUA, and the WUALN considered the variant of integration to the UALN on the autonomy rights.

Key words: The Western Ukrainian Association of the League of Nations; the League of Nations Union of Associations; the government of Western Ukrainian National Republic in exile; the Eastern Galicia; the Polish State.

Introduction

The League of Nations Union of Associations (LNUA) of was created in Paris (France) in January 1919. According to the words of a member of The Western Ukrainian Association of the League of Nations (WUALN) O. Maritchak, the action "became a crucial step on the way of 
reaching global peace"1. The Ukrainian Association of the League of Nations was established by the emigrants from Naddniprianschina who were the adherences of Ukrainian National Republic (UNR) government in exile in Vienna (Austria) in autumn 1921 that gave powerful impetus to foundation of the Western Ukrainian Association of the League of Nations (WUALN). The Western Ukrainian political emigration began meticulous organizational work regarding refinement of an ideological platform and staff of a new association which was embodied in the association's creation in 1922.

The foreign policy of WUALN in the first half of the 1920-s was an unknown page in modern Ukrainian and foreign historiography. There are no special studies which are able to describe the general activity of the WUALN's representatives at the congresses of the LNUA, reveal the cooperation with Ukrainian and European political parties and represent an endeavor to solve "the Ukrainian issue" in the tough geopolitical conditions of the 1920-s.

The aim of the issue is to provide a comprehensive analysis of the WUALN creation's peculiarities, study its foreign political activity in 1922-1924, and define the effectiveness of the work of its representatives at the LNUA's congresses.

The article is based on the vast resourceful material, the base of which is consisted of the archive materials of the Central State Historical Archive of Ukraine in Lviv (CSHAL Ukraine), in particular fond 355 "The Western Ukrainian Association of the League of Nations, Vienna", fond 382 "Ulian Romanchuk, a political and public figure, teacher, writer, journalist, 1842-1923". Moreover the materials of the periodic press of that time were used (namely, a journal "Business")

\section{Methods}

The principles of historicism, systematic and objectivity applied to the approach of highlighting the past actions on the base of the complex study of resources and scientific literature form the methodological core of the issue. The general scientific methods (systematization, typologization and retrospection), the special historical methods (problem-chronological, historical-comparative bibliographical methods and a method of critical analysis) were used to solve the objectives of the issue.

\section{Results}

The practical steps aimed at the WUALN's creation were initiated at the end of 1921. In the letter to the President of Ukrainian National Republic (UNR) from the $11^{\text {th }}$ of December 1921, the future president of the WUALN R. Perfetskyi offered to establish three organizations: the WUALN itself, Ukrainian Association of the League of Nations and separate Association for the Kuban's lands according to the agreements of the foreign group of Ukrainian National Labor Party (UNLP). Simultaneously he proposed a project of establishment of the integrated Ukrainian association - the League of Nations Union of Associations of the Ukrainian lands with the aim of their activity's coordination ${ }^{2}$.

R. Perfetskyi mentioned that "all the threats and dangerous which had been brought to the Western-

\footnotetext{
1 Західно-Українське товариство Ліаи Націй, м. Відень. Центральний державний історичний архів України у м. Львові. (далі - ЦДІАЛ України) Fond 355. List 1. File14. Page 1 ["The Western Ukrainian Association of the League of Nations, Vienna, "Central State Historical Archive of Ukraine in Lviv.]

2 ЦДІАЛ України. Fond 355. List 1. File2. Page 1 [Central State Historical Archive of Ukraine in Lviv.]
}

Ukrainian territories and had an ambiguous character which determined the state policy of separate territories would be illuminated" 3 under the circumstances of establishment of three Ukrainian associations. According to him, the contradictions existed between the residents of Naddniprianschina and Galicia due to the status's issue of the Ukrainian lands could paralyze the activity of a common Ukrainian Lands' Association of the League of Nations, namely "they could bring inadequacy to it and owing to the internal disputes were able to harm its respect and total existence" ${ }^{4}$. Simultaneously the creation of a coordination body - the League of Nations Union of Associations of the Ukrainian lands would permit to illuminate the "harmful influences of the foreign cultures on the mental state, well-being, political upbringing and the methods of work which had been composed for centuries on the separated territories" and facilitate "the common recognition of the ways, political conceptions and orientations" 5 .

On the $12^{\text {th }}$ of December 1921 R. Perfetskyi's propositions about establishment of three Ukrainian associations were considered at the meeting of a foreign group of the UNLP which ratified the decision about a necessity of the WUALN's foundation according to the tough geopolitical conditions ${ }^{6}$. The constituent assembly of the WUALN occurred on the $20-23^{\text {rd }}$ of January 1922 . The Presidency and the Main Board of Association were elected at the meeting after a statute had been adopted, furthermore political platform was refined, the resolutions and directives for the elected Board were ratified.

The Presidency was represented by: Roman Perfetskyi (The President), Ernest Braiter, Osip Nazaruk (the President's comrades), llia Semaka, Kyrylo Trylovskyi, Oleksander Martichak (a secretary), O. losafat Jean (a secretary's deputy), Ital Vitischynskyi (a treasurer). The Main Board included: Agenor Artymovich, Osip Karanovych, Ivan Kossak, Oleksander Kulachkovskyi, Kost Levitskyi, Lev Levitskyi, Wilhelm Naiman, Lev Petruschevich, Jaroslav Podliaschetskyi. The deputies of the Main Board members were Dmytro Koropatnytskyi, Ivan Nimchuk and Ivan Okolot? ${ }^{7}$. "Consequently, the Ukrainians, Polish and Jews had been included to the Presidency and the Main Board, who secured the state independence of the Western Ukrainian lands, - Perfetskyi noted. - Moreover during the process of the Presidency and a head of the Board election, it was mentioned that the rest places would be reserved for the nations which had not been presented in the Association yet" ${ }^{8}$. The statute was developed by $U$. Romanchuk and R. Perfetskyi. It was mentioned that "The Association should keep the main terms of the agreement of the League of Nations and facilitate its practical embodiment on the Western Ukrainian lands and in those Ukrainian regions which according to the Treaty of SaintGermain and owing to their independence from the former Austro-Hungarian Empire are the separate object of international law and act under the sovereignty of Antanta countries" 9 . The WUALN was stressed to support the League of Nations' initiatives aimed at "elimination of

\footnotetext{
${ }^{3}$ Ibid.

4 Ibid

5 lbid.

${ }^{6}$ lbid.

7 ЦДІАЛ України. Fond 355. List 1. File 14. Page 1 [Central State Historical Archive of Ukraine in Lviv.]

${ }^{8}$ ЦДІАЛ України. Fond 355. List 1. File 14. Page 2 [Central State Historical Archive of Ukraine in Lviv.]

9 ЦДІАЛ України. Fond 382. List 1. File 9. Page 1 [Central State Historical Archive of Ukraine in Lviv.]
} 
injustice, law of force and disempowerment in the international legal relations"10. The fact would permit "to secure free development to all nations according their right on self-identification" 11

The WUALN's foundation was only the first step to the full membership in the LNUA. Having into account the counteraction of the Polish association of the same name and the reluctance of some European countries to solve "the Ukrainian issue", a tough target was put before the WUALN, the solution of which needed consolidated work of Ukrainian political emigration and national consciousness of Galicia's elite.

On the $1^{\text {st }}$ of April 1922 the WUALN's foundation sent letters to the Main Secretary of the LNUA and to the English, French, Italian, Belgium, German, Russian, Hungarian associations where the WUALN was offered to be accepted into the LNUA on the basis of statutory documents of international organization ${ }^{12}$

The WUALN's members mentioned that paragraph 3 of the LNUA's statute involved the option of including to the association the countries "which did not belong to the independent state units, however according to the countries they were included in, presented independent / federation I state units, the population of which was secured by autonomous rights" 13 .

The sixth Congress of the LNUA took place in Prague (Czechoslovakia) on the $3^{\text {rd }}-7^{\text {th }}$ of June 1922 . The additional aim of the congress "was to spread the general recognition of the Western Ukrainian Association of the League of Nations and facilitate its acceptance to the union"14. A substantial delegation came to the congress, represented by: R. Perfetskyi (a head of the delegation), K. Tryliovskyi, I. Semak, O. Maritchak, and the representatives of the association's branch in Prague (M. Lozynskyi (a head of the branch), O. Kolessa, L. Davydovskyi, K. Gladiy, R. Scheparovych). The WUALN's members remembered that "Our delegation provided broad and intensive propaganda among the members of the Congress aimed at acceptance of the Western Ukrainian Association, however the situation was unproductive for us owing to the strong counteraction of the Polish delegates during the first days of the event". Afterwards, "according to the unsuccessful endeavor of postponing the decision of our Association's acceptance at the congress on the $5^{\text {th }}$ of June, the documents proposed by our association to the first and fifth Commission in the speech of Doctor O. Maritchak should be considered before being submitted to the Congress"15.

O. Maritchak and M. Lozynskyi made the presentations "State and Legal Situation of the Western Galicia's Problem" and "The Historical Basis of our State" respectively on behalf of the WUALN at the meeting of the fifth commission on the $6^{\text {th }}$ of June 1922. Afterwards, "there were the answers and the claims especially about our Association's status from the Polish delegates Count Los and Professor Dembinskyi on which Doctor O. Maritchak answered on behalf of our delegation" 16 .

The conclusion of the extended discussions of the

\footnotetext{
10 Ibid.

$11 \mathrm{lbid}$.

12 ЦДІАЛ України. Fond 355. List 1. File 8. Page 1 [Central State Historical Archive of Ukraine in Lviv.]

13 ЦДІАЛ України. Fond 355. List 1. File 2. Page 4 [Central State Historical Archive of Ukraine in Lviv.]

14 ЦДІАЛ України. Fond 355. List 16. File 1. Page 1 [Central State Historical Archive of Ukraine in Lviv.]

15 lbid.

16 ЦДІАЛ України. Fond 355. List 1. File 16. Page 2 [Central State Historical Archive of Ukraine in Lviv.]
}

ISSN 1728-9343 (Print)

ISSN 2411-3093 (Online)
WUALN representatives' reports was in accepted resolutions which noted the following: "Taking into account the specific state of the Eastern Galicia (the Western Ukraine) and its recognition by the big countries of Antanta and the numerous decisions issued on the case, the Commission decided to consider it as a separate land" (proposition of Great Britain accepted by 15 voices "for", 1 - "against", 3 "abstained"). "The sixth conference decided that the legal situation of the Eastern Galicia had been remained unclear and regarding to the great difficulties created by the present state of the territory, the wishes were expressed to solve the issue of a legal status of the Eastern Galicia in the short terms" (The offer of Holland delegation was adopted unanimously) ${ }^{17}$

The meeting of the first Commission of domestic affairs took place on the $7^{\text {th }}$ of June 1922. A decision about urgent necessity of the unity between the WUALN and the LNUA was adopted unanimously at the meeting (Polish delegate abstained). The report about "The Problem of the Eastern Galicia" was presented by O. Maritchak. The plenary meeting of a Congress adopted unanimously a resolution of accepting the WUALN to the LNUA after the lunch the same day; moreover, "afterwards, after the speech of Great Britain delegation the resolutions were given". The WUALN's delegation mentioned that "the adopted resolution was met by Congress's applause" 18 .

Having become the full member of the LNUA, the WUALN started the meticulous work for solving "the Ukrainian issue" at the congresses of the international organization. In September 1922 the WUALN defined the delegates to the congress of the LNUA in Budapest (Hungary): R. Perfetskyi, O. Maritchak, Valdman ("the main members"), M. Lozynskyi, L. Levytskyi, F. Jean (deputies) ${ }^{19}$. The representatives from 18 European countries took part at the conference; furthermore, there were the delegations from Argentina, China and Japan. Despite the lack of finance, the WUALN sent R. Perfetskyi, O. Maritchak, F. losafat and B. Baranova to Budapest ${ }^{20}$.

In the WUALN's information report it was mentioned that "the three-days conference of the Board of the League of Nations Union of Associations in Budapest aimed at preparing the general conference of the Union appointed to Vienna in the spring 1923, in addition to the cases of the formal character regarding to the internal organization of the Union" 21. Simultaneously, the association initiated a project of resolution where the necessity of temporary sovereignty of the Eastern Galicia's claim from the countries of Antanta was mentioned ... in order to "proceed immediately for performing the self-rights of the territory and for illuminating all Polish governmental acts issued by the military occupational power of the Eastern Galicia which violated the sovereignty and integral unity of the lands, introduced national, physical, economic and cultural illumination of the Ukrainian majority and the Jewish minority in the Eastern Galicia"22.

A long-term consideration of the WUALN's proposition concluded with the adoption where the necessity of a detailed analysis of social and political processes in Galicia was determined at the conference in Vienna (Aust-

\footnotetext{
$17 \mathrm{lbid}$.

18 ЦДІАЛ України. Fond 355. List 1. File16. Page 3 [Central State Historical Archive of Ukraine in Lviv.]

19 ЦДІАЛ України. Fond 355. List 1. File13. Page 1 [Central State Historical Archive of Ukraine in Lviv.]

$20 \mathrm{lbid}$.

21 lbid.

22 ЦДІАЛ України. Fond 355. List 1. File8. Page 4 [Central State Historical Archive of Ukraine in Lviv.]
}

SKHID No. 4 (162) July-August 2019 
ria) in 1923. The President of the WUALN R. Perfetskyi observed that "acceptance of the Western Galicia's issue to the program of the General Conference of Union in Vienna should be considered as a significant achievement of our delegation. The general political situation should be taken into account: the internal disturbance in Italy, a political defeat of Lloyd George in England, Turkish victory over the Greeks in the Asia Minor, all the enumerated events caused the vast reserve of the single delegations that endeavored to omit any debates over the tough European issues. Nevertheless, the Western Galicia's issue became a subject of substantial discussions and impressed the delegates far more than the issue of Greek and Turkish conflict which was considered afterwards, where nobody took part except the parties concerned"23.

Still the Board of the Antanta's ambassadors ratified a decision concerned the Eastern Galicia's transmission to Poland on the $14^{\text {th }}$ of March 1923. A de-jure fact excluded the WUALN's membership from the LNUA ${ }^{24}$. Consequently, the main objective of the WUALN's delegation at the conference of the LNUA was not a solution of "the Ukrainian issue", however a struggle for saving a full membership in the international organization in Vienna (in June 1923) ${ }^{25}$. Nonetheless, the argumentation of Ukrainian representatives did not satisfy the Main Board of the LNUA which suspended the representative rights of the WUALN in the association. The Ukrainian delegation left the Vienna conference after a relevant protest ${ }^{26}$.

The WUALN was faced with a rhetorical question after the membership' suspension in the LNUA: "What tactics should be chosen under the new social and political conditions?" The WUALN's Presidency applied to the famous politicians of Galicia, namely to E. Petruschevich, U. Romanchuk and etc., and to the WUALN's branch in Prague, the Interparty Council and Ukrainian National Republic with the request about obtaining any prompt of an optional choice: 1) Withdrawal from the LNUA with a relevant protest; 2) Entrance to the UALN on the federation's basis; 3 ) Creation of common delegation with the Polish association of the League of Nations.

The Council of Ukrainian National Labor Party (UNLP) recommended the WUALN to remain the independent organization in the LNUA in the letter to the WUALN's Presidency of the $14^{\text {th }}$ of June $1923^{27}$. The same position was taken by the older man of Ukrainian politicians $U$. Romanchuk, who was elected as an honorable member of the WUALN. He rejected the variant of union with the Polish association of the League of Nations in his letter to E. Petruschevich of the $7^{\text {th }}$ of June 1923: "Such union is beyond any discussions, as it will accept the Polish statehood as well as exclude any possibility to protect our independence in the future". The President of UNR offered "to enter to Paddniprianskaya's section of the League of Nations with remaining autonomy and appropriate protection in the management and at the general meetings of Union" 28

On behalf of the Prague branch of the WUALN, M. Lo-

\footnotetext{
23 ЦДІАЛ України. Fond 355. List 1. File8. Page 6 [Central State Historical Archive of Ukraine in Lviv.]

24 ЦДІАЛ України. Fond 355. List 1. File50. Page 24 [Central State Historical Archive of Ukraine in Lviv.]

25 ЦДІАЛ України. Fond 355. List 1. File9. Page 1 [Central State Historical Archive of Ukraine in Lviv.]

26 Ibid.

${ }^{27}$ ЦДІАЛ України. Fond 355. List 1. File50. Page 18 [Central State Historical Archive of Ukraine in Lviv.]

28 ЦДІАЛ України. Fond 355. List 1. File50. Page 24 [Central State Historical Archive of Ukraine in Lviv.]
}

zynskyi considered the two cardinal alternatives: "1) to leave the Union when you will be rejected as a representation of a particular land, making a statutory objection; 2) or organize a Ukrainian association in Poland on the basis similar to the German association in Czech Republic" ${ }^{29}$. The last idea was supported by the WUALN's representatives.

As an outcome, an initiative meeting was convened referred to the establishment of Lviv Association of the League of Nations due to an initiative of the nationally conscious Ukrainian society in Lviv on the $11^{\text {th }}$ of October 1923. As the meeting began, the mayor of police Vagner accompanied by the police officers appeared in the room and dispersed the constituent assembly on the grounds of even accepting an invitation to the assembly was "a crime of betrayal against the Polish state" ${ }^{30}$. The participants of the assembly proclaimed a protest that was signed by $\mathrm{O}$. Ochrymovich, O. Maritchak, F. Fedortsiv on the $16^{\text {th }}$ of October $1923^{31}$.

At the same period, on the $8^{\text {th }}-11^{\text {th }}$ of October 1923 , the regular conference of the Main Board of the LNUA was held in The Hague (Holland), where 31 delegates from the American and European Associations took part. On behalf of the UALN, a founding member of Ukrainian Association, A. Yakovlev was presented. Owing to the Polish governmental impediments the WUALN's representatives had no opportunity to accede to the conference.

A. Yakovlev applied to the Presidency of the Council of the LNUA and asked on behalf of the WUALN "to include an issue of Galicia's Association in the agenda of the General meeting of Union and simultaneously to address to the Polish Association to influence on the Polish governmental organizations with the aim of eliminating the impediments to the Association members' move to Galicia" on the $9^{\text {th }}$ of October $1923^{32}$.

Nevertheless, the Presidency of the LNUA did not have enough time to consider the WUALN's declaration. Responding to the Galicia members' accusations, "a Polish representative Fedorovich declared that the question had been already solved, everything had been done, however the Galicia's members did not have any desire to move, etc. Proving the fact, the General Secretary gave a reference that one member of the association had already moved to Lviv indeed, still, the others had not moved yet as they did not have the passports" ${ }^{33}$. At the same time a representative of the UALN requested to renew the rights of the WUALN, as "the issue had not been completely solved to that time" 34 .

The general meeting of the WUALN was held prior to the LNUA's conference on the $11^{\text {th }}$ of March 1924. The results of the annual activity were presented on them. Their participants stated that "on the occasion of the coming solution about state and legal position of the Eastern Galicia, the association included to all state and civil international organizations the references about creation of the independent Western Ukrainian state institutions on the Western-Ukrainian lands represented by the Eastern Galicia, Volyn, Pidliasche, Polissia and the North-Western Bukovina and to the League of Nations Union of Associa-

${ }^{29}$ ЦДІАЛ України. Fond 355. List 1. File54. Pages 3-9 [Central State Historical Archive of Ukraine in Lviv.]

30 ЦДІАЛ України. Fond 355. List 1. File45. Page 1 [Central State Historical Archive of Ukraine in Lviv.]

$31 \mathrm{lbid}$.

32 ЦДІАЛ України. Fond 355. List 1. File45. Page 4 [Central State Historical Archive of Ukraine in Lviv.]

33 lbid.

34 lbid. 
tions the notes of interests' violation among other countries" ${ }^{35}$. The new governing bodies were elected at the general meeting of the WUALN: the association's Presidency - R. Perfetskyi (the President), M. Gavrysevich (the VicePresident), A. Petruschevich (the Main Secretary), G. Myketey (the Second Secretary), A. Zuk (a Treasurer); to the Association's Main Board were elected K. Levytskyi, A. Vitoschynskyi, I. Valdyman, I. Kossak, M. Gamota and the fifth members from Galicia; the deputies of the Main Board members became: I. Nimchuk, I. Prots and V. Bachyntskyi; the members of the Control Commission were elected I. Karanovych, I. Kuropatnytskyi and U. Demchyna ${ }^{36}$.

The regular congress of the LNUA was in Lyon (France) on the $27^{\text {th }}$ of June - the $4^{\text {th }}$ of July 1924 . The social and political processes in the Eastern Galicia were considered at the congress. "In order to follow the issue" 37 , the WUALN's delegation of R. Perfetskyi, A. Petruschevich and $\mathrm{O}$. Maritchak came to France ${ }^{38}$. The representatives of the delegation clearly understood that "a final fight of the further existence of the Western Ukrainian Association of the League of Nations in Union was in Lyon". The fact strengthened the significance of the event for the association's members as well as to the Ukrainians from Galicia in general ${ }^{39}$.

The WUALN meticulously prepared to the conference. In addition to the "Memorandum about the situation on the Western Ukrainian lands included to Poland", dozens of documents were prepared that proved the disempowered position of the Ukrainians in the Second Rzeczpospolita and revealed anti-Ukrainian national and cultural policy of the central and local authorities. R. Perfetskyi applied to the Council of Ukrainian National Labor Party (UNLP) to prepare the relevant documents in May 1924. The President of the WUALN observed that "we needed to prove all our statements with the original examples to the extent possible, namely using the original documents from the Polish authorities, stenographic protocols with the speeches from Polish Sejm, cuttings from the magazines, especially the Polish ones for securing our success of all actions in Union" 40 .

The WUALN's delegation gave to the Main Secretary of the LNUA Rissenov and the Head of National Minorities Commission Dikenson "a Substantiated Letter" for returning the WUALN to the structure of the League of Nations Union of Associations and "Memorandum about the situation on the Western Ukrainian lands included to Poland"41 soon after their arrival to Lyon on the $26^{\text {th }}$ of June 1924. The WUALN requested to consider complains of Ukrainian organizations about the arbitrariness of the Polish authorities to the Ukrainians and noted the violations from the Polish side of national minorities' agreement of the $28^{\text {th }}$ of June $1919^{42}$.

The first conversation with Rissein, the most authoritative member of the League of Nations Union of Asso-

\footnotetext{
${ }_{35}$ ЦДІАЛ України. Fond 355. List 1. File17. Page 2 [Central State Historical Archive of Ukraine in Lviv.]

36 lbid.

37 ЦДІАЛ України. Fond 355. List 1. File22. Page 1 [Central State Historical Archive of Ukraine in Lviv.]

38 Ibid.

39 ЦДІАЛ України. Fond 355. List 1. File56. Page 1 [Central State Historical Archive of Ukraine in Lviv.]

40 ЦДІАЛ України. Fond 355. List 1. File57. Page 7 [Central State Historical Archive of Ukraine in Lviv.]

41 ЦДІАЛ України. Fond 355. List 1. File56. Page 8 [Central State Historical Archive of Ukraine in Lviv.]

42 ЦДІАЛ України. Fond 355. List 1. File22. Page 1 [Central State Historical Archive of Ukraine in Lviv.]
}

ISSN 1728-9343 (Print)

ISSN 2411-3093 (Online) ciations, demonstrated his reluctance to solve the problem of the Ukrainians from the Second Rzeczpospolita. R. Perfetskyi mentioned that "he had to admit that we were right to apply to the former Union's membership which we still possessed, however he stated that all speakers of that Board had clearly expressed their opinion that our association should be moved to Poland, accept Polish statehood and enter to the Polish delegation"43.

On the $28^{\text {th }}$ of June 1924 the LNUA considered an issue of renewing the rights of the WUALN in the Union that required from the Ukrainians to "follow the issue locally" 44.

The edits that excluded any opportunity of the WUALN's participation in the work of the Union were made in the Statute of an international organization in advance, namely referred to paragraph 3 which regulated the associations' participation in the work of organization; there the word "land" was substituted by the word "state". Consequently, as R. Perfetskyi wrote, the Statute's changes led to the "failure" of the most crucial argument for the WUALN's participation in the Union's work. Moreover, he concluded that "the Statute's changes were obviously directed against our Association" ${ }^{45}$. Nevertheless, according to him "it was necessary to take any part in order to reveal the situation behind the Union's curtains, defend our business in any possible way... and to force the ruling circles to respect their own decisions in the case" ${ }^{46}$.

The final decisions of the Lyon Conference caused resentment among the population of Galicia. In particular, the journal "Business" criticized the participation of the WUALN's members at the general meeting of the League of Nations Union of Associations in Lyon. In the editorial devoted to "The Issue of Congress in Lyon" 47 an author wrote: "We need to admit openly and sincerely that the issue [in Lyon - author's] has finished with the complete failure... We could predict that the delegates would not be allowed to present at the meeting... and participation in the international meetings without careful consideration of all circumstances of a presentation is a complete waste of money" 48

Answering to the criticism of his opponents, the President of the WUALN responded that participation of the association's representatives in the work of the Lyon Conference "brought the useful results to our national case under the modern tough circumstances as well as the essence of the issue was not into simple acceptance to the participation at the meetings in Lyon". R. Perfetskyi summarized: "We knew quite well that our representational issue would have a dead end in the Union, consequently our organization could not participate in the Union's meetings as a full member with the right to vote, etc." ${ }^{49}$.

The head of the WUALN persuaded the opponents that "the development of our case required from us to obtain the necessary funds and appeared in Lyon in order to follow the case personally and tried to transfer it to the Union's consideration on the grounds of our own presence" ${ }^{50}$. Nonetheless, R. Perfetskyi admitted with sorrow,

\footnotetext{
43 ЦДІАЛ України. Fond 355. List 1. File56. Page 12 [Central State Historical Archive of Ukraine in Lviv.]

44 lbid.

45 lbid.

46 Ibid.

473 нагоди конгресу в Ліоні. Діло. [The Issue of Congress in Lyon. Business.] 1924. Ч. 157. С. 1.

48 ЦДІАЛ України. Fond 355. List 1. File22. Page 1 [Central State Historical Archive of Ukraine in Lviv.]

49 ЦДІАЛ України. Fond 355. List 1. File22. Page 2 [Central State Historical Archive of Ukraine in Lviv.]

50 ЦДІАЛ України. Fond 355. List 1. File22. Page 3 [Central State Historical Archive of Ukraine in Lviv.]
}

SKHID No. 4 (162) July-August 2019 
that "the Ukrainian issue" had to be considered at the meeting of the committee, however, subsequently in lieu of "the disadvantage for the Union's matters of Vilno and Bessarabia... it was excluded from the agenda" ${ }^{51}$.

The Main Board of the WUALN considered the report of the Association's Head R. Perfetskyi of the delegation's trip to France and accepted a resolution approved by the Association in Lyon, about an intention of finishing the work in the LNUA on the $9^{\text {th }}$ of July $1924^{52}$. Maritchak's report (a representative of the Ukrainian National Labor Party) about the international activity of the WUALN in the light of the Lyon Conference was presented at the meeting of UNLP on the $15^{\text {th }}$ July the same year. It was concluded that after the association's secession "its international activity could not be stopped, by contrast the association should provide the comprehensive activity aimed at defense of the national and governmental rights of the residents of the Western Ukrainian lands" ${ }^{53}$.

\section{Discussion}

The representatives of the local Ukrainian political national-oriented parties, Ukrainian political emigration endeavored to use the format of international organization, in particular the LNUA for solving "the Ukrainian issue" under the Polish government system in Galicia at the beginning of the 1920-s. With the ideas of independence and unity of Ukraine, the WUALN (established in 1922) was aimed at posing the problem of a legal status of the

${ }^{51}$ ЦДІАЛ України. Fond 355. List 1. File22. Page 17 [Central State Historical Archive of Ukraine in Lviv.]

52 ЦДІАЛ України. Fond 355. List 1. File10. Page 1 [Central State Historical Archive of Ukraine in Lviv.]

$53 \mathrm{lbid}$.
Ukrainian lands at the international scene, facilitating in "the Ukrainian issue's" solution at the international level, despite all counteracts from the governmental authorities of the Second Rzeczpospolita.

\section{Conclusions}

In 1922 the WUALN obtained a full membership of the LNUA. An event caused a very strong reaction in Galicia as well as in the environment of Ukrainian political emigration. The great expectations for solving the problem of Ukrainian statehood and withdrawing the Polish occupation were connected with the association. The association was under "the control" of the Western Ukrainian National Republic (WUNR) in exile that tried to "eliminate the Polish and Romanian occupation on the Western Ukrainian lands as soon as possible" ${ }^{54}$. Considering the WUALN's participation in the work of a congress of the League of Nations Union of Associations, it should be stated that it was not very successful: the position of the Ukrainians in the Second Rzeczpospolita was not substantively considered at the meetings of the international organization, and after the decision of the Board of the Antanta's ambassadors from the $14^{\text {th }}$ of March 1923, was excluded from the organization. Afterwards, during 1924-1928 the WUALN's representatives made unsuccessful endeavors to renew their activity in the LNUA, from one hand, and to establish an association of the League of Nations in Lviv, from the other. The numerous protests, appeals to the address of the Board of League of Nation, The Presidency of the LNUA, supported by UPR had predominantly promotional effect of informing the international community about nonrecognition of the Western Ukraine affiliation to Poland.

54 ЦДІАЛ України. Fond 355. List 1. File14. Pages 3-4 [Central State Historical Archive of Ukraine in Lviv.]

Соляр Ігор,

Інститут українознавства ім. I. Крип'якевича НАН Украӥни;

Начіональна академія сухопутних військ імені Петра Сагайдачного (м. Львів, Україна)

e-mail: isoliar@ukr.net, ORCID 0000-0003-0439-6957

Фіногенов Олег,

Інститут украӥнознавства ім. І. Крип'якевича НАН Украӥни (м. Львів, Україна)

e-mail:fom_178@ukr.net, ORCID0000-0002-6666-1624

Скорич Лілія,

Національна академія сухопутних військ імені Петра Сагайдачного (м. Львів, Украйна)

e-mail: skorychl@ukr.net, ORCID 0000-0003-3162-517X

\section{ЗАХІДНО-УКРАЇНСЬКЕ ТОВАРИСТВО ЛІГИНАЦІЙ: ІДЕОЛОГІЧНА ПЛАТФОРМА, ДІЯЛЬНІСТЬ НА КОНГРЕСАХ СОЮЗУ ТОВАРИСТВ ЛІГИ НАЦІЙ (1922 - 1924)}

Західно-Українське товариство Ліги Націй (ЗУТЛН) - одна з провідних еміграційних організаційних структур західноукраїнських політичних діячів, створених з метою розширення впливу на міжнародному рівні екзильного уряду ЗУНР для вирішення проблеми державного статусу Східної Галичини. Товариство у 1922 - 1924 рр. виступало на міжнародній арені захисником національно-державницьких інтересів українців Галичини, пропагувало ідею відновлення української державності після завершення Першої світової війни. Мета статті проаналізувати особливості створення товариства, його зовнішньополітичну діяльність, охарактеризувати ефективність роботи керівних органів ЗУТЛН, діяльність представників товариства у Союзі Товариств Ліги Націй (СТЛН), акцентувати на співпраці з політичними партіями Західної України.

Ключові слова: Західно-Українське товариство Ліги Націй; Союз Товариств Лізи Націй; еміграційний уряд ЗУНР; Східна Галичина; Польська держава.

@) Soliar Ihor, Finogenov Oleh, Skoruch Lilija

Надійшла до редакції: 19.07.2019

Прийнята до друку: 15.08.2019

СХІД № 4 (162) липень-серпень 2019 р. 